\title{
Effects of Trialkyllead Compounds on Growth, Respiration and Ion Transport in Escherichia coli $\mathrm{K} 12$
}

\author{
By JANE F. GIBSON, S. GAYE HADFIELD, * MARTIN N. HUGHES \\ AND ROBERT K. POOLE† \\ Departments of Microbiology and Chemistry, Queen Elizabeth College \\ (University of London), Campden Hill, London W8 $7 \mathrm{AH}$
}

(Received 28 March 1979)

\begin{abstract}
Triethyllead and tripropyllead cations affected growth, energy metabolism and ion transport in Escherichia coli K12. The tripropyllead compound was more liposoluble than the triethyl analogue and was also more effective in inhibiting cell growth and the oxygen uptake of both intact cells and membrane particles. Triethyllead acetate $(5 \mu \mathrm{M})$ inhibited growth on non-fermentable carbon sources, such as glycerol and succinate, more markedly than on glucose. At higher concentrations, triethyllead caused significant inhibition of respiration rates of intact cells; the concentration giving $50 \%$ inhibition was $60 \mu \mathrm{M}$ for glycerol-grown cells and $150 \mu \mathrm{M}$ for glucose-grown cells. Oxidation of succinate by membrane particles was less sensitive to inhibition by the tripropyl- or triethyllead compounds than were the oxidations of DL-lactate or NADH. Triethyllead acetate $[1.9 \mu \mathrm{mol}(\mathrm{mg}$ membrane protein $)^{-1}$ ] inhibited the reduction by NADH of cytochromes; evidence for more than one site of inhibition in the respiratory chain was obtained. Membrane-bound ATPase activity was strongly inhibited by triethyllead acetate in the absence or presence of $\mathrm{Cl}^{-}$. The concentration of inhibitor giving $50 \%$ inhibition $\left.[0.02 \mu \mathrm{mol} \text { (mg membrane protein })^{-1}\right]$ was about two orders of magnitude lower than that required for $50 \%$ inhibition of substrate oxidation rates in membranes. Triethyllead acetate $(1 \mu \mathrm{M})$ induced swelling of spheroplasts in iso-osmotic solutions of either $\mathrm{NH}_{4} \mathrm{Cl}$ or $\mathrm{NH}_{4} \mathrm{Br}$, presumably as a result of the mediation by the organolead compound of $\mathrm{Cl}^{-} / \mathrm{OH}^{-}$and $\mathrm{Br}^{-} / \mathrm{OH}^{-}$antiports across the cytoplasmic membrane. Similar exchanges of $\mathrm{OH}^{-}$for $\mathrm{F}^{-}, \mathrm{NO}_{3}{ }^{-}$or $\mathrm{SO}_{4}{ }^{2-}$ or the uniport of $\mathrm{H}^{+}$could not be demonstrated. Comparisons are drawn between the effects of trialkyllead compounds and those of the more widely studied trialkyltin compounds.
\end{abstract}

\section{INTRODUCTION}

Organolead compounds are more toxic than inorganic lead compounds due to their greater liposolubility and ready absorption through biological membranes. Alkyllead compounds, particularly tetraethyllead, are used on a massive scale as 'anti-knock' agents in petrol. Tetraethyllead is dealkylated in the liver to form the triethyllead cation, which is believed to be the principal toxic form (Stevens et al., 1960; Cremer, 1962; Bolanowska, 1968).

Concern over the toxicity of organolead compounds has generated research into its biochemical basis. As might be expected from their similar chemical properties, the biochemical effects of triorganolead compounds are similar to those of triorganotin compounds, which are widely used as biocides (Aldridge, 1976). Both classes of organometallic com-

* Present address: Department of Bacteriology, Wright-Fleming Institute, St Mary's Hospital Medical School, London W2.

$\dagger$ To whom reprint requests should be sent at the Microbiology Department. 
pounds stimulate ATP hydrolysis by rat-liver mitochondria and increase state- $4 \mathrm{O}_{2}$ uptake (Aldridge \& Street, 1971); both these effects are dependent on the presence of $\mathrm{Cl}^{-}$in the medium (Rose \& Aldridge, 1972). Recently, Aldridge et al. (1977) have shown that each of five organotin and five organolead compounds perturb mitochondrial function in three different ways: (i) mediation of a $\mathrm{Cl}^{-} / \mathrm{OH}^{-}$exchange across membranes (Selwyn et al., 1970); (ii) interaction with mitochondria to produce oligomycin-like inhibition of oxidative phosphorylation (Stockdale et al., 1970); and (iii) gross swelling of mitochondria (Aldridge $\&$ Street, 1964). The organotin compounds have received increased attention because of the finding that dibutyltin dichloride (Cain et al., 1977a) and dibutylchloromethyltin chloride (Cain et al., 1977b) are potent inhibitors of the oligomycin-sensitive adenosine triphosphatase (ATPase) of yeast. Inhibition by the dibutylchloromethyltin compound is due to a covalent interaction with a non-protein, lipophilic compound of the inner mitochondrial membrane, perhaps lipoic acid, which is proposed to be a cofactor or intermediate of oxidative phosphorylation (Cain et al., 1977b).

The effects of organolead and organotin compounds on bacteria have been less extensively studied. However, it has recently been shown that triethyltin compounds stimulate respiration rates of Escherichia coli membrane vesicles suspended in $\mathrm{Cl}^{-}$-containing medium and inhibit succinate oxidation by intact cells. These effects have been attributed to the mediation of a $\mathrm{Cl}^{-} / \mathrm{OH}^{-}$antiport (Leow \& Leaver, 1977), suggesting that this mode of action is widespread in membrane systems.

In the present paper, we describe the effects on $E$. coli $\mathrm{K} 12$ of three trialkyllead compounds of different liposolubility. These compounds exert pleiotropic effects on growth, respiration and ATPase activity as well as mediating a halide $/ \mathrm{OH}^{-}$exchange (antiport). Parts of this work have been presented previously (Gibson et al., 1979).

\section{METHODS}

Organism and growth conditions. Escherichia coli strain A1002 (K12 Y mel ilv lacI metI) was provided by Dr B. A. Haddock and grown on the medium described by Poole \& Haddock (1974). The trace element solution was modified from that described by Pirt (1967) and contained $\left(\mathrm{g} \mathrm{l}^{-1}\right): \mathrm{Na}_{2} \mathrm{EDTA}_{2}$. $\mathrm{H}_{2} \mathrm{O}, 5$; $\mathrm{FeCl}_{3} .6 \mathrm{H}_{2} \mathrm{O}, 0.5 ; \mathrm{ZnO}, 0.05 ; \mathrm{CuCl}_{2} .2 \mathrm{H}_{2} \mathrm{O}, 0.01 ; \mathrm{Co}\left(\mathrm{NO}_{3}\right)_{2} .6 \mathrm{H}_{2} \mathrm{O}, 0.01 ; \mathrm{H}_{3} \mathrm{BO}_{3}, 0.01 ;\left(\mathrm{NH}_{4}\right)_{6} \mathrm{Mo}_{7} \mathrm{O}_{24} .4 \mathrm{H}_{2} \mathrm{O}$, 0.01 . The medium was further supplemented with $\mathrm{L}$-isoleucine, L-valine and L-methionine (all at $0.002 \%$, $\mathrm{w} / \mathrm{v}$ ) and Casamino acids (Difco; $0.1 \%, \mathrm{w} / \mathrm{v}$ ). Carbon sources were glycerol, glucose or succinate (each at $5 \%, \mathrm{w} / \mathrm{v}$ ). The chloride content of the complete medium was about $20 \mathrm{~mm}$.

Growth studies were performed with $20 \mathrm{ml}$ cultures shaking in $250 \mathrm{ml}$ Erlenmeyer flasks fitted with sidearms for turbidity measurements; larger quantities of cells were grown as $400 \mathrm{ml}$ batches in 21 Erlenmeyer flasks. In all cases, growth was at $37^{\circ} \mathrm{C}$ and flasks were shaken at $250 \mathrm{rev}$. $\mathrm{min}^{-1}$. Cultures were inoculated from overnight cultures growing in the same medium. The susceptibility of growth to inhibition by trialkyllead compounds was unaffected by the volume of culture shaken.

Preparation of membrane particles. Cells from 2.8 to 5.61 of culture were harvested in the exponential phase of growth by centrifugation at $4^{\circ} \mathrm{C}$ either at $2500 \mathrm{rev} . \mathrm{min}^{-1}$ for $30 \mathrm{~min}$ in the $6 \times 11$ rotor of an MSE Mistral $6 \mathrm{~L}$ centrifuge or using a continuous-flow rotor cperating at $16000 \mathrm{rev}$. $\mathrm{min}^{-1}$ and a flow rate of about $280 \mathrm{ml} \mathrm{min} \mathrm{m}^{-1}$ in an MSE 18 centrifuge. Cells were washed twice in a medium that contained $50 \mathrm{~mm}-\mathrm{Tris} / \mathrm{HCl}$, $2 \mathrm{~mm}-\mathrm{MgCl}_{2}$ and $1 \mathrm{~mm}$-EGTA (Poole \& Haddock, 1974). The chloride content of the buffer was $44 \mathrm{~mm}$. Washed cells were stored frozen overnight and, after thawing, were disrupted ultrasonically (five periods of $30 \mathrm{~s}$, each separated by $15 \mathrm{~s}$ ) in an MSE $150 \mathrm{~W}$ ultrasonicator. The probe had an end diameter of $2 \mathrm{~mm}$ and was operated at an amplitude of 4 to $5 \mu \mathrm{m}$ (peak-to-peak). Fractionation of the disrupted cells by differential centrifugation was done as described by Poole \& Haddock (1974) to yield a membrane particle fraction ('electron transport particles').

Preparation of spheroplasts. These were prepared exactly as described by Garland et al. (1975). Spheroplasts were resuspended at 0 to $4{ }^{\circ} \mathrm{C}$ in a buffer that contained $0.5 \mathrm{M}$-sucrose and $10 \mathrm{~mm}$-glycylglycine (pH 7.0) to a protein concentration of about $10 \mathrm{mg} \mathrm{ml}^{-1}$ using one or two strokes of a loose-fitting hand homogenizer. Osmotic swelling was studied by following the change in turbidity at $500 \mathrm{~nm}$, using a Unicam SP1700 spectrophotometer, following dilution of the spheroplast suspension into the iso-osmotic solutions described in Results. 
Measurement of cell growth. Culture growth was routinely followed turbidimetrically using an EEL colorimeter fitted with a green 404 filter. Growth was expressed as arbitrary turbidity units. One unit is equivalent to about $1 \times 10^{8}$ bacteria $\mathrm{ml}^{-1}$.

Measurement of oxygen uptake. Respiration rates were measured using either a conventional, closed Clark-type electrode system or, when steady-state respiration rates were to be measured, an open $\mathrm{O}_{2}$ electrode system (Degn et al., 1973; Poole, 1977). In the latter, the value of $K$, the constant for the first-order diffusion of $\mathrm{O}_{2}$ from the atmosphere into the cell suspension, was 0.92 to $1.98 \mathrm{~min}^{-1}$. In all cases the temperature was $37^{\circ} \mathrm{C}$ and the volume of suspension was $2.0 \mathrm{ml}$.

Cytochrome spectra. Difference spectra were recorded at $77 \mathrm{~K}$ using a Unicam SP1700 split-beam spectrophotometer with low temperature accessories. Cuvettes were of $2.5 \mathrm{~mm}$ path length and were cooled to $77 \mathrm{~K}$ prior to 'steady-state trapping' as described by Chance \& Schoener (1966). Absorption coefficients used were those given by Haddock et al. (1976).

Assay of ATPase activity (EC 3.6.1.3). Method III of Tsuchiya \& Rosen (1975), which incorporates an ATP-regenerating system, was modified only as described below. For assay of activity in the absence of $\mathrm{Cl}^{-}, \mathrm{NO}_{3}^{-}$salts were used throughout. The final $\mathrm{Cl}^{-}$content of the $\mathrm{Cl}^{-}$-containing assay mixture was $55 \mathrm{~mm}$. About 100 to $150 \mu \mathrm{g}$ particle protein was used for assay. After termination of the incubation by addition of trichloroacetic acid, the protein was removed by centrifugation at $4{ }^{\circ} \mathrm{C}$ and inorganic phosphate in the supernatants was assayed by adding $3 \mathrm{ml}$ of a reagent that contained $1.7 \%(\mathrm{w} / \mathrm{v})$ ascorbic acid, $0.82 \%(\mathrm{w} / \mathrm{v})$ ammonium molybdate and $0.82 \mathrm{M}-\mathrm{H}_{2} \mathrm{SO}_{4}$. After further incubation for 30 min the absorbance was read at $660 \mathrm{~nm} ; \mathrm{KH}_{2} \mathrm{PO}_{4}$ (AnalaR grade) was used as a standard. Phosphate release was linear with respect to time and protein concentration under the conditions used. Appropriate controls allowed for non-enzymic ATP hydrolysis and for contamination of the assay components with $P_{i}$ or ATP.

Protein was determined by Lowry's method, using dry bovine plasma albumin as standard.

Determination of partition coefficients of trialkyllead salts. An aqueous solution of the organolead compound was prepared containing about $20 \mu \mathrm{g}$ lead $\mathrm{ml}^{-1}$. A portion $(25 \mathrm{ml})$ was shaken with an equal volume of 1 -octanol for $2 \mathrm{~h}$ in a stoppered flask and the lead content of the separated aqueous and organic phases was determined using a Hilger \& Watts Atomspek atomic absorption spectrometer. Solutions to be analysed were each refluxed for $15 \mathrm{~min}$ with conc. $\mathrm{HNO}_{3}$ ( 1 part per 5 parts solution), thus resulting in con:plete conversion of organic lead to inorganic lead. The instrument was calibrated with standard solutions of inorganic lead. The partition coefficient was calculated as (concentration of lead in 1-octanol)/(concentration of lead in aqueous layer).

Chemicals. Triethyllead acetate and tripropyllead acetate were from Ventron Alfa, Beverley, Mass., U.S.A. Triethyllead chloride was prepared by a standard method involving the reaction between tetraethyllead and concentrated hydrochloric acid. Carbonyl cyanide $m$-chlorophenylhydrazone (CCCP), NADH (grade III, disodium salt) and ATP (disodium salt) were from Sigma, Triton X-100 was from Koch-Light, and sodiumDL-lactate from K \& K L aboratories, Hollywood, Calif., U.S.A. All other reagents, including lysczyme, were from $\mathrm{BDH}$.

\section{RESULTS}

\section{Inhibition of growth by trialkyllead compounds}

The results of adding trialkyllead compounds to cultures growing with glycerol as carbon source are shown in Fig. 1 $(a)$. The effects of triethyllead chloride and triethyllead acetate, each at $10 \mu \mathrm{M}$, were indistinguishable from each other; both compounds extended the mean generation time from about $1 \mathrm{~h}$ in the absence of the inhibitor to $5.8 \mathrm{~h}$. Thus, the contributions, if any, of the $\mathrm{Cl}^{-}$and acetate anions to the overall toxicity of the added compounds were similar. In contrast, the nature of the alkyl groups was an important determinant of toxicity. Tripropyllead acetate $(1 \mu \mathrm{M})$ was a more potent inhibitor than $2 \mu \mathrm{M}$-triethyllead acetate (Fig. 1a). Total inhibition of growth on glycerol was achieved with $50 \mu \mathrm{M}$-triethyllead acetate (results not shown).

Growth on non-fermentable carbon sources such as glycerol or succinate was more susceptible to inhibition by triethyllead compounds than was growth on glucose (Fig. $1 b$ ). Mean generation times on glucose and glycerol in the absence of triethyllead acetate were each about $1 \mathrm{~h}$ and were extended to $2 \mathrm{~h}$ and $5 \mathrm{~h}$, respectively, after adding the organolead compound. There was a progressive decrease in the rate of growth of succinate-grown cells after adding the inhibitor. These results suggest that functions linked to non-glycolytic 


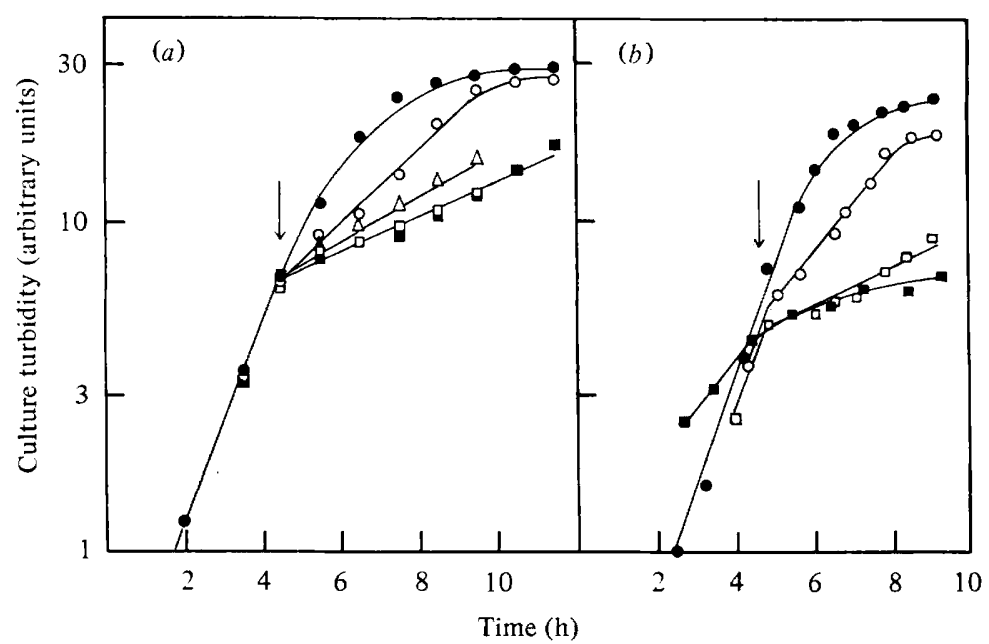

Fig. 1. Inhibition of growth of $E$. coli K12 by trialkyllead compounds. The control culture ( $)$ was grown on glycerol-containing medium. (a) At the time indicated by the arrow, aqueous solutions of trialkyllead compounds were added to give the final concentrations indicated: triethyllead acetate, $2 \mu_{\mathrm{M}}(\mathrm{O})$ and $10 \mu_{\mathrm{M}}(\square)$; triethyllead chloride, $10 \mu_{\mathrm{M}}(\square)$; tripropyllead acetate, $1 \mu_{\mathrm{M}}(\triangle)$. (b) At

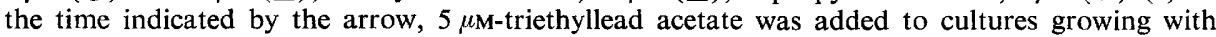
glucose $(\bigcirc)$, glycerol $(\square)$ or succinate $(\square)$ as carbon source.

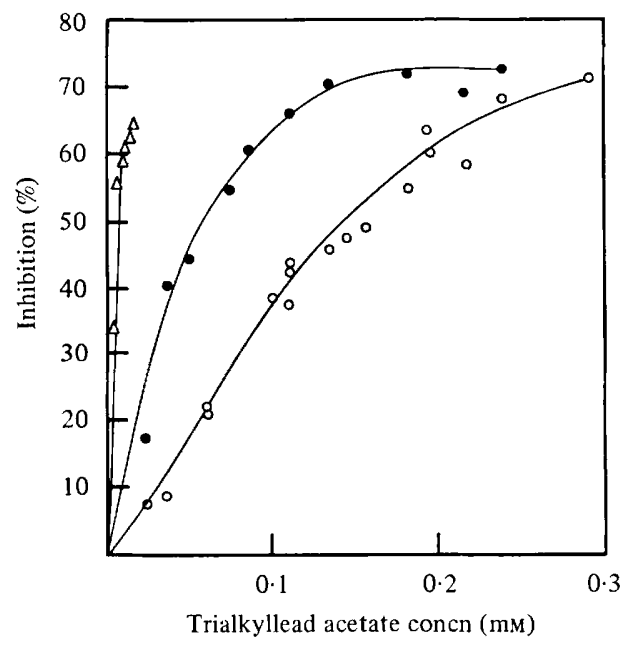

Fig. 2. Inhibition of respiration rates of intact cells by trialkyllead acetates. Respiration rates were measured polarographically in a conventional closed vessel on untreated samples from cultures in the mid-exponential phase of growth. The inhibition was determined after addition of tripropyllead acetate to cells grown with glycerol $(\triangle)$ and triethyllead acetate to cells grown with glycerol $(\mathbf{O})$ and glucose $(\bigcirc)$. Samples for all experiments contained approx. $4 \times 10^{8}$ cells $\mathrm{ml}^{-1}$.

energy generation (and thus the ability to grow on non-fermentable substrates) are preferentially inhibited by organolead compounds.

\section{Inhibition of oxygen uptake of intact cells}

Addition of trialkyllead acetates to samples removed from exponentially growing cultures inhibited respiration rates (Fig. 2). Respiration rates of glycerol-grown cells were more sensitive to inhibition by triethyllead acetate than those of glucose-grown cells. Values of $I_{50}$ (i.e. the concentration of inhibitor giving $50 \%$ inhibition of respiration) were 0.06 and 


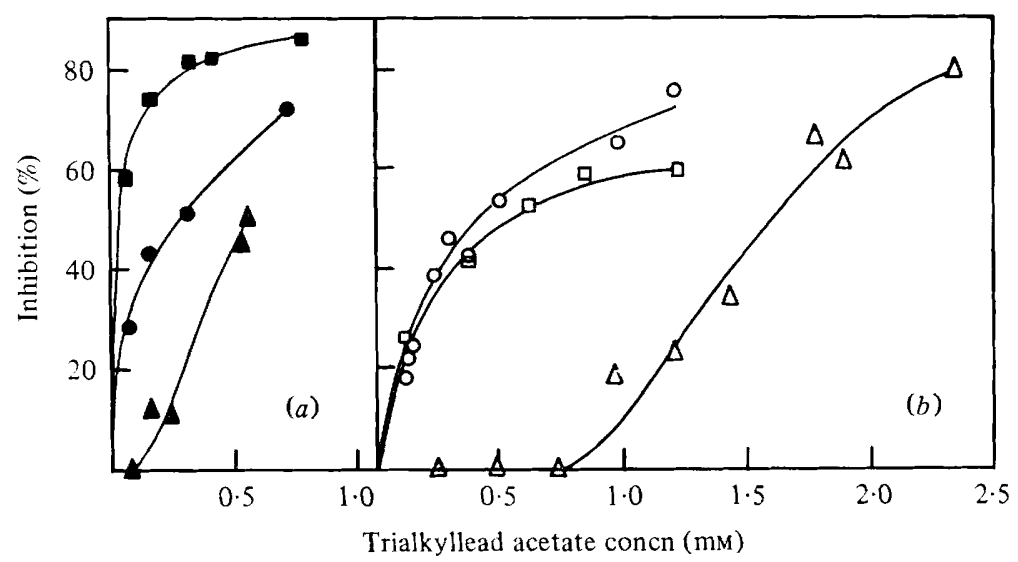

Fig. 3. Inhibition of respiration rates of membrane particles by tripropyllead acetate (a) and triethyllead acetate $(b)$. Membrane particles were prepared from ultrasonically disrupted exponentialphase cells as described in Methods, and respiration rates were measured in a conventional closed $\mathrm{O}_{2}$ electrode system. Substrates were $0.62 \mathrm{~mm}-\mathrm{NADH}(\boldsymbol{O}, \bigcirc), 0.93 \mathrm{~mm}$-sodium succinate $(\boldsymbol{\Delta}, \Delta)$ and $4.46 \mathrm{~mm}$-sodium DL-lactate $(\square, \square)$. Final protein concentration was $0.27 \mathrm{mg} \mathrm{ml}^{-1}$.

$0.15 \mathrm{~mm}$ for glycerol- and glucose-grown cells, respectively. About 20 to $30 \%$ of the respiration remained insensitive to inhibition, even with the inhibitor at up to $0.4 \mathrm{~mm}$ (results not shown). Like growth (Fig. 1a), respiration was more sensitive to the tripropyl derivative than the triethyl derivative, the $I_{50}$ for tripropyllead acetate with glycerol-grown cells being about $0.01 \mathrm{mM}$. The apparent $I_{50}$ for triethyllead acetate was dependent on the cell density used. For glycerol-grown cells, the $I_{50}$ increased from 0.06 to $1.4 \mathrm{~mm}$ when the culture turbidity at the time of removing samples increased from 3.4 to 6.0 turbidity units, whilst for glucose-grown cells the $I_{50}$ increased from 0.14 to $0.22 \mathrm{mM}$ when the culture turbidity increased from 2.5 to 6.9 turbidity units.

\section{Inhibition of oxygen uptake of membrane particles}

The greater toxicity of tripropyllead acetate compared with the triethyl derivative was further reflected in the inhibition observed for membrane particles oxidizing various added substrates (compare Fig. $3 a$ and $b$ ). For each inhibitor, succinate oxidation was less sensitive to the presence of trialkyllead acetate than were the oxidations of DL-lactate and NADH. The apparent $\mathbf{I}_{\mathbf{5 0}}$ was dependent on the amount of membrane protein used in the assay of respiration rates. Expressed with respect to protein concentration, the mean $I_{5 c}$ values for triethyllead acetate measured in three experiments (in which the protein concentration varied between 0.27 and $0.75 \mathrm{mg} \mathrm{ml}^{-1}$ ) were $1.5,2.0$ and $5.9 \mu \mathrm{mol}(\mathrm{mg} \text { protein })^{-1}$ for the oxidation of NADH, lactate and succinate, respectively. One such experiment is shown in Fig. 3(b). Corresponding values for inhibition by tripropyllead acetate were $1 \cdot 0,0 \cdot 2$ and $2 \cdot 0 \mu \mathrm{mol}$ (mg protein) $)^{-1}$ (Fig. $3 a$ ).

\section{Steady-state reduction levels of cytochromes in the presence and absence of triethyllead acetate}

The open oxygen electrode affords convenient measurement of the rate of steady-state respiration immediately before trapping the steady state by cooling to $77 \mathrm{~K}$. Furthermore, examination of steady states representing dissimilar respiration rates at similar oxygen tensions is possible. The difference spectrum between the reduced steady state (particles oxidizing NADH) and the oxidized steady state (particles oxidizing endogenous substrates) (Fig. $4 a$ ) shows the presence of at least two $b$-type cytochromes absorbing in the $\alpha$-region of the spectrum. The major peak is at $558 \mathrm{~nm}$ with a distinct shoulder at $560 \mathrm{~nm}$, although the 


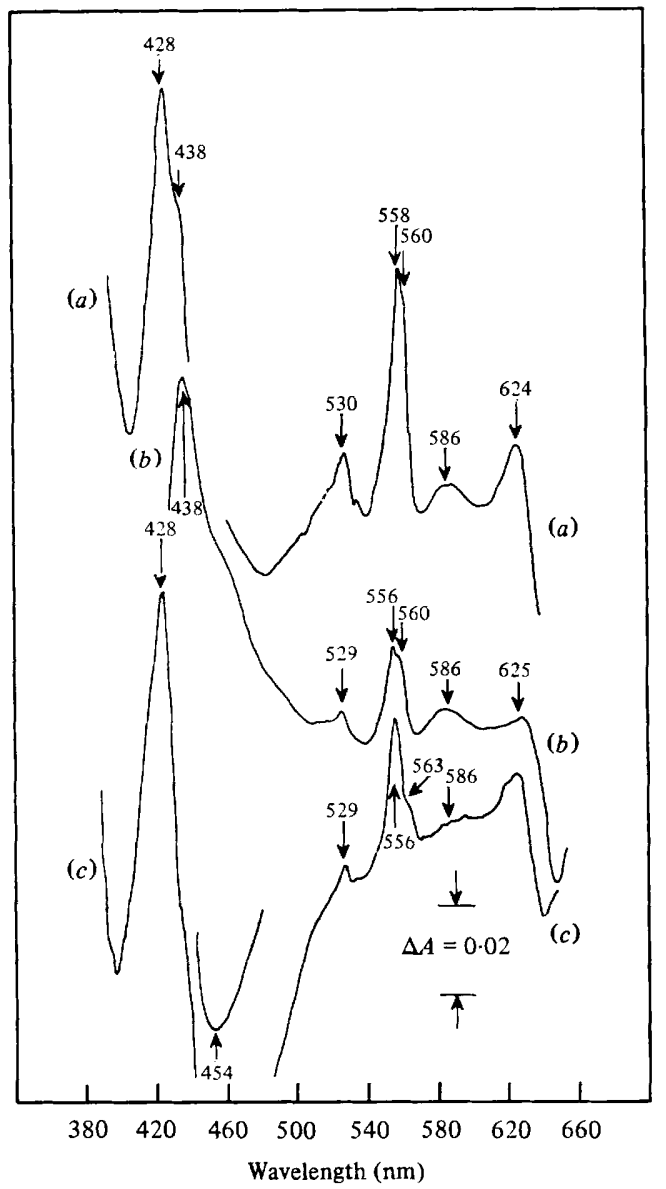

Fig. 4. Steady-state difference spectra of membrane particles and the effect of triethyllead acetate. Membrane particles suspended in disruption buffer were incubated in an open $\mathrm{O}_{2}$ electrode vessel in the absence or presence of triethyllead acetate [final concn $1.9 \mu$ mol (mg protein) $)^{-1} ; 25 \mathrm{mM}$ ]. After addition of NADH $\left(6.25 \mathrm{~mm}\right.$, final concn) a lower steady-state level of $\mathrm{O}_{2}$ tension was established. Samples were trapped in each of three steady states by rapid transfer of the suspension to pre-cooled $(77 \mathrm{~K})$ brass-walled cuvettes of $2.5 \mathrm{~mm}$ path length. The difference spectra recorded [and the respiration rates, in $\mathrm{nmol} \mathrm{O}_{2} \mathrm{~min}^{-1}(\mathrm{mg} \text { protein })^{-1}$, at the time of freezing] were: $(a)$ NADH-reduced (32) minus oxidized $(1 \cdot 4) ;(b)$ NADH-reduced in the presence of triethyllead acetate (14.6) minus oxidized (1.4); (c) NADH-reduced (32) minus NADH-reduced in the presence of triethyllead acetate (14.6). Spectrum $(b)$ was recorded using a spectral band width of $0.6 \mathrm{~nm}$ and a scanning speed of $1 \mathrm{~nm} \mathrm{~s}^{-x}$; spectra $(a)$ and $(c)$ were recorded using a band width of $0.8 \mathrm{~nm}$ and a scanning speed of $2 \mathrm{~nm} \mathrm{~s}^{-1}$. Final protein concentration was $13 \mathrm{mg} \mathrm{ml}^{-1}$. The $\mathrm{O}_{2}$ concentrations in the NADH-supplemented suspensions immediately prior to freezing and the value of $K$ (the firstorder rate constant for the diffusion of $\mathrm{O}_{2}$ into the suspension) were $6.8 \mu \mathrm{M}$ and $1.98 \mathrm{~min}^{-1}$, respectively, for the suspension lacking triethyllead; corresponding values for the suspension to which inhibitor was added were $9.0 \mu \mathrm{M}$ and $0.92 \mathrm{~min}^{-1}$.

spectrum in this region is broad and at least three $b$-type cytochromes probably contribute (Shipp, 1972). Further components are revealed in spectra $(b)$ and $(c)$. Cytochromes of the $b$-type are also seen in the $\gamma$-region at $428 \mathrm{~nm}$. The presence of cytochrome $o$ in these particles was confirmed in CO-reduced minus reduced difference spectra (not shown). Cytochromes $a_{1}$ (absorption maximum 586 to $\left.590 \mathrm{~nm}\right)$ and $d\left(a_{2}\right.$; absorption maximum $625 \mathrm{~nm}$ ) were both present as would be expected in cells grown to the late-exponential phase of growth. Addition of triethyllead acetate to a suspension of particles [final concn $1.9 \mu \mathrm{mol}$ ( $\mathrm{mg}$ protein $)^{-1}$ ] before NADH resulted in an oxidation rate of the substrate that was only 


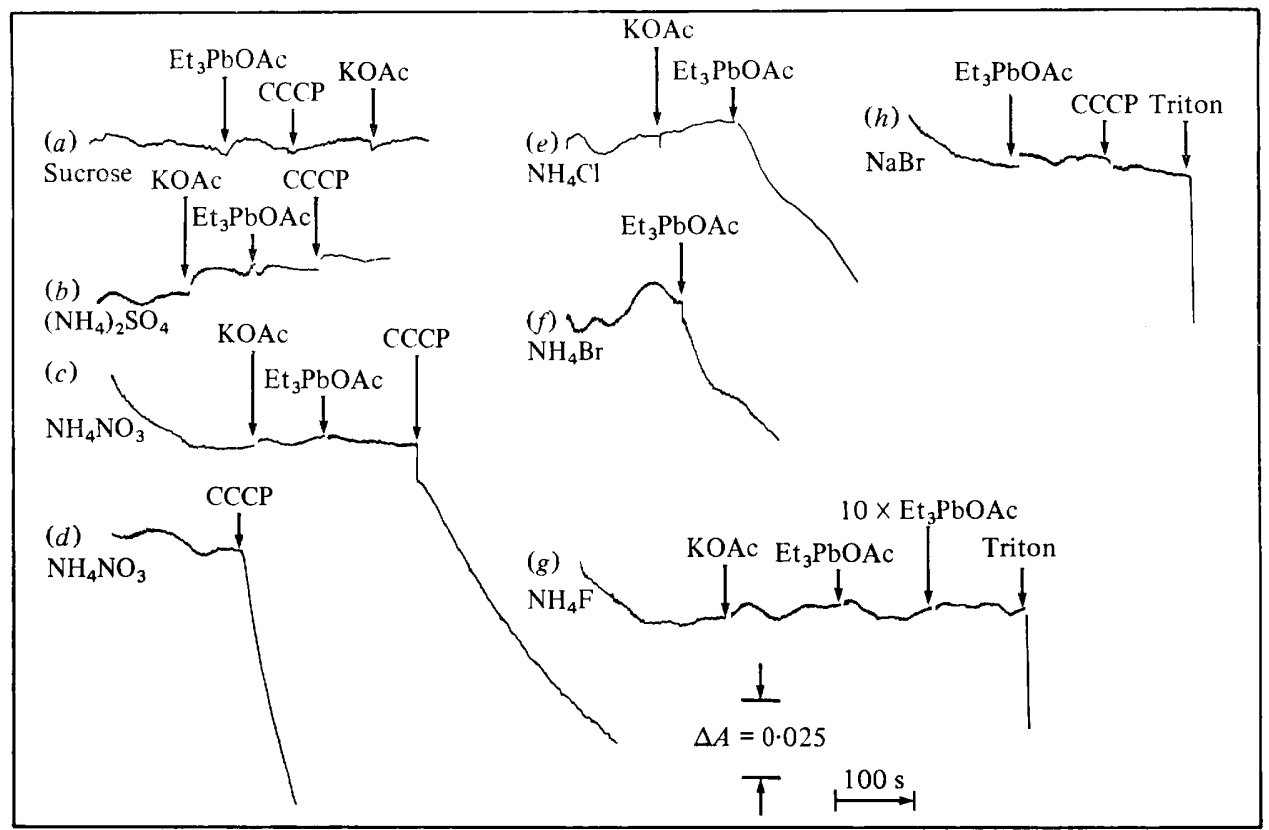

Fig. 5. Osmotic behaviour of spheroplasts in iso-osmotic salt solutions and the effects of triethyllead acetate. Osmotic swelling was followed spectrophotometrically at $500 \mathrm{~nm}$ in a cuvette of $1 \mathrm{~cm}$ light path after addition of $50 \mu \mathrm{l}$ of the spheroplast suspension (described in Methods) to $2.5 \mathrm{ml}$ of the indicated iso-osmotic solution at $21^{\circ} \mathrm{C}$. CCCP was added as $2.5 \mu \mathrm{l}$ of a methanolic $4.9 \mathrm{~mm}$ solution and Triton X-100 as $25 \mu \mathrm{l}$ of a $1 \%(\mathrm{v} / \mathrm{v})$ aqueous solution. Triethyllead acetate $\left(\mathrm{Et}_{3} \mathrm{PbOAc}_{\mathrm{C}}\right.$ and potassium acetate (KOAc) were each added as $5 \mu$ of an aqueous solution, giving a final concentration of $1 \mu \mathrm{M} .10 \times \mathrm{Et}_{3} \mathrm{PbOAc}$ indicates the addition of $5 \mu \mathrm{l}$ of a more concentrated solution, giving a final concentration of $10 \mu \mathrm{M}$. The iso-osmotic solutions were $(a) 0 \cdot 5 \mathrm{M}$-sucrose, $(b) 0 \cdot 17 \mathrm{M}-\left(\mathrm{NH}_{4}\right)_{2} \mathrm{SO}_{4}$, $(c)$ and $(d) 0.25 \mathrm{M}-\mathrm{NH}_{4} \mathrm{NO}_{3},(e) 0.25 \mathrm{M}-\mathrm{NH}_{4} \mathrm{Cl},(f) 0.25 \mathrm{M}-\mathrm{NH}_{4} \mathrm{Br},(g) 0.25 \mathrm{M}-\mathrm{NH}_{4} \mathrm{~F}$ and $(h) 0.25 \mathrm{M}-$ $\mathrm{NaBr}$. Time proceeds from left to right and a downward deflection indicates spheroplast swelling.

$46 \%$ of the respiration in the absence of inhibitor (see also Fig. $3 b$ ). Cytochromes of the $b$-type (absorption maxima at about $428 \mathrm{~nm}$ and 556 to $563 \mathrm{~nm}$ ), flavoprotein (trough at 450 to $480 \mathrm{~nm}$ ) and cytochrome $d$ (maximum at $624 \mathrm{~nm}$ ) were all less reduced by NADH in the presence of triethyllead acetate (Fig. $4 b$ ). The most striking feature of the spectrum is the shift in the Soret absorption maximum from about $428 \mathrm{~nm}$ (indicative of $b$-type cytochromes) to about $438 \mathrm{~nm}$ (indicative of $a$-type cytochromes). Examination of the $\alpha$-region of the spectrum shows that the level of reduction of $a_{1}$ (maximum at $586 \mathrm{~nm}$ ) is less markedly changed. Thus, trialkyllead acetate results in decreased reduction of both $b$-type and $d$ cytochromes, the effect on the former being more marked. Spectrum $(c)$ in Fig. 4 is that of the difference between the NADH-reduced sample and that reduced by NADH in the presence of triethyllead acetate; it illustrates those components that become more oxidized in the presence of the inhibitor. The Soret band is centred at $428 \mathrm{~nm}$; the contribution from cytochrome $d$ is small. The constancy of the reduction level of cytochrome $a_{1}$ in the absence or presence of inhibitor is confirmed.

\section{Mediation of a transmembrane halide $/ \mathrm{OH}^{-}$exchange by triethyllead acetate}

Spheroplasts, being osmotically sensitive, resist volume changes only when suspended in an iso-osmotic solution in which the dissolved solutes do not penetrate the cytoplasmic membrane. If solute originally in the supporting medium crosses the vesicle membrane, it contributes to the internal osmotic pressure, water follows to maintain osmotic balance and the spheroplasts swell, causing a decrease in light scattering. Figures 5(a) and $(b)$ show 
(a)

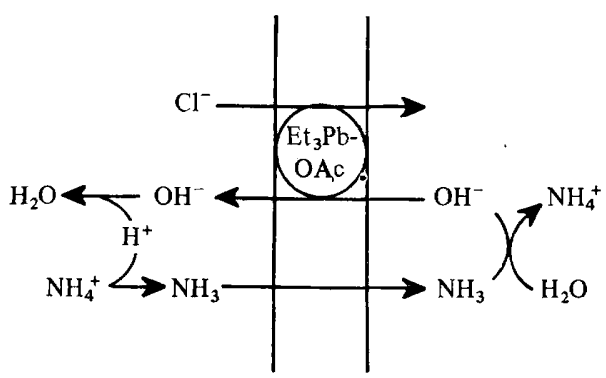

(c)

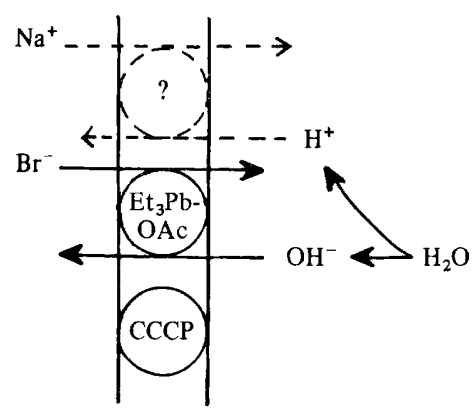

(b)

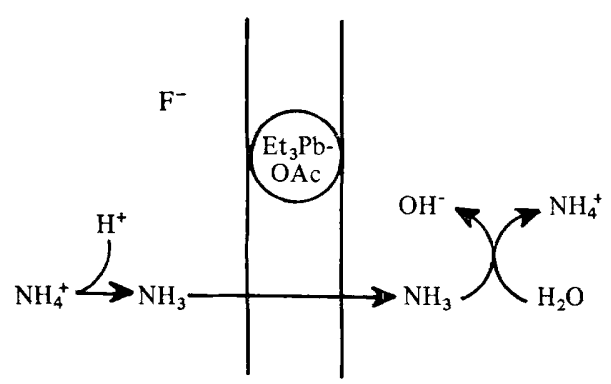

(d)

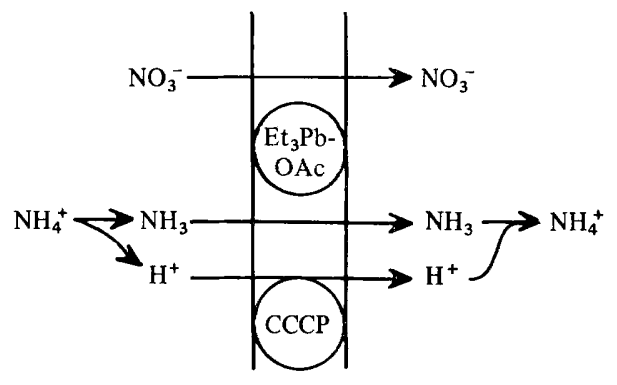

Fig. 6. Involvement of triethyllead acetate in transmembrane ion movements in spheroplasts suspended in ammonium halides, ammonium nitrate and sodium bromide. In each scheme $(a$ to $d)$, the pair of vertical lines represents the cytoplasmic (spheroplast) membrane, with the cytoplasm on the right and extracellular space on the left. Large circles in the membrane represent specific pathways provided by triethyllead acetate $\left(\mathrm{Et}_{3} \mathrm{PbOAc}\right)$ for $\mathrm{Cl}^{-} / \mathrm{OH}^{-}$exchange or $\mathrm{Br}^{-} / \mathrm{OH}^{-}$exchange and by $\mathrm{CCCP}$ for $\mathrm{H}^{+}$movement. Passive diffusion is shown for $\mathrm{NO}_{3}^{-}$and $\mathrm{NH}_{3}$ (Garland et al., 1975; Mitchell \& Moyle, 1969). These schemes explain entry of solutes as follows. In (a), entry of $\mathrm{NH}_{4} \mathrm{Cl}$ (or $\mathrm{NH}_{4} \mathrm{Br}$ ) and spheroplast swelling is shown. In (b), the ineffectiveness of $\mathrm{Et}_{3} \mathrm{PbOAc}$ in facilitating a $\mathrm{F}^{-} / \mathrm{OH}^{-}$exchange does not lead to swelling. In (c), charge imbalance prevents swelling despite the presence of the $\mathrm{Et}_{3} \mathrm{PbOAc}$-mediated $\mathrm{Br}-/ \mathrm{OH}^{-}$exchange; operation of the $\mathrm{Na}^{+} / \mathrm{H}^{+}$antiport (West \& Mitchell, 1974) shown by the broken lines would result in swelling. In $(d), \mathrm{NH}_{4} \mathrm{NO}_{3}$ enters and causes swelling in the presence or absence of $\mathrm{Et}_{3} \mathrm{PbOAc}$, provided that CCCP is present.

that $0.5 \mathrm{M}$-sucrose or $0.17 \mathrm{M}-\left(\mathrm{NH}_{4}\right)_{2} \mathrm{SO}_{4}$ meets the requirements of an osmotic stabilizer and that low concentrations of triethyllead acetate, the uncoupler CCCP or the acetate anion have no effect on the osmotic behaviour of the vesicles. Similarly, iso-osmotic $0.25 \mathrm{M}-\mathrm{NH}_{4} \mathrm{NO}_{3}$ is an osmotic stabilizer in the absence or presence of the triethyllead cation (Fig. 5c). Figures $5(c)$ and $(d)$ also show that the presence of CCCP is a necessary and sufficient condition for osmotic swelling in solutions of $\mathrm{NH}_{4} \mathrm{NO}_{3}$. In contrast, the stability of spheroplasts in iso-osmotic $\mathrm{NH}_{4} \mathrm{Cl}$ (Fig. $5 e$ ) or $\mathrm{NH}_{4} \mathrm{Br}$ (Fig. $5 f$ ) is lost on addition of $1 \mu \mathrm{M}$-triethyllead acetate whilst the acetate anion is without effect (Fig. 5e). Figure $5(\mathrm{~g})$ shows that another ammonium halide, $\mathrm{NH}_{4} \mathrm{~F}$, provides osmotic support even in the presence of $10 \mu \mathrm{M}$-triethyllead acetate. The swelling on addition of the detergent Triton $\mathrm{X}-100$ demonstrates that the spheroplasts used in this assay were indeed osmotically sensitive. $\mathrm{NaBr}$ provides osmotic support in the presence of triethyllead acetate or CCCP, but not Triton X-100 (Fig. 5h).

Figure 6 presents schemes that attempt to rationalize the observations in Fig. 5. Extensive spectrophotometrically detectable swelling occurs only when the overall transport processes are electrically neutral and produce no net movement of $\mathrm{H}^{+}$or $\mathrm{OH}^{-}$across the membrane. Scheme $(a)$ shows the non-electrogenic movement of $\mathrm{NH}_{4}{ }^{+}$and $\mathrm{Cl}^{-}$ions facilitated by the 


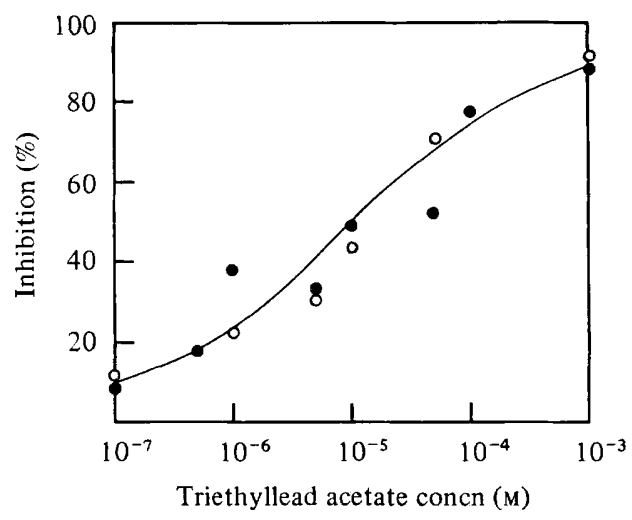

Fig. 7. Inhibition of ATPase activity of membrane particles by triethyllead acetate. Membrane particles were prepared from ultrasonically disrupted cells and ATPase activity in medium with (O) or without (O) $\mathrm{Cl}^{-}$was assayed by phosphate release, as described in Methods. Each assay was performed with $0 \cdot 14 \mathrm{mg}$ membrane particle protein.

presence of triethyllead acetate. Even though ammonia (as $\mathrm{NH}_{3}$ ) diffuses passively across the membrane, the $\mathrm{pH}$ gradient induced by its movement and ionization resists further solute movements in the absence of the triethyllead ion. A similar mechanism is presumed to explain spheroplast swelling in $\mathrm{NH}_{4} \mathrm{Br}$ induced by triethyllead acetate. The lack of swelling in $\mathrm{NH}_{4} \mathrm{~F}$ is interpreted as a result of the inability of the triethyllead ion to mediate a $\mathrm{F}^{-} / \mathrm{OH}^{-}$exchange (Fig. $6 b$ ). Lack of swelling in $\mathrm{NaBr}$ results from the charge imbalance caused by the apparent impermeability of the membrane to $\mathrm{Na}^{+}$(Fig. 6c). Triethyllead acetate is ineffective in providing a pathway for $\mathrm{H}^{+}$, whilst CCCP is effective and induces swelling in iso-osmotic $\mathrm{NH}_{4} \mathrm{NO}_{3}$ (Fig. $6 d$ ). Nitrate has previously been shown to diffuse passively across the membrane (Garland et al., 1975). In summary, the triethyllead ion mediates a $\mathrm{Cl}^{-} / \mathrm{OH}^{-}$or $\mathrm{Br}^{-} / \mathrm{OH}^{-}$exchange but $\mathrm{F}^{-}, \mathrm{SO}_{4}{ }^{2-}$ and $\mathrm{NO}_{3}{ }^{-}$ions do not participate in similar anion $/ \mathrm{OH}^{-}$exchanges.

\section{Inhibition by triethyllead acetate of ATPase activity}

Triethyllead acetate was a potent inhibitor of ATPase activity in membrane particles, with an $\mathrm{I}_{50}$ of about $0.023 \mu \mathrm{mol}$ (mg protein) $)^{-1}$ (Fig. 7). Up to $90 \%$ inhibition was obtained with an inhibitor concentration of $2 \cdot 3 \mu \mathrm{mol}$ (mg protein) $)^{-1}$. The inhibition was independent of the presence of $\mathrm{Cl}^{-}$in the assay medium.

\section{Partition coefficients for trialkyllead acetate}

The partition coefficients for triethyllead and tripropyllead acetates between 1-octanol and water were $0 \cdot 86 \pm 0.02$ and $16 \cdot 7 \pm 5 \cdot 0$, respectively, indicating the greater liposolubility of the latter.

\section{DISCUSSION}

Triorganolead compounds exert a variety of effects on growth and metabolism of E. coli. These are: (i) inhibition of growth, particularly on non-fermentable carbon sources; (ii) inhibition of $\mathrm{O}_{2}$ uptake rates of intact cells; (iii) inhibition of $\mathrm{O}_{2}$ uptake and of reduction of flavoprotein and cytochromes in membrane particles; (iv) inhibition of ATPase activity; and (v) mediation of a halide $/ \mathrm{OH}^{-}$antiport in spheroplasts. Many of these effects are likely to be manifestations of common underlying mechanism(s). However, discrimination between diverse mechanisms on the basis of the concentration of triorganolead required to produce a given effect is frustrated by the finding that inhibition is dependent on the amount 
of biological material present in the assay system, and that different forms of cellular material (viz. intact cells, spheroplasts, membrane particles) are used. Nevertheless, some direct comparisons are possible. Complete inhibition of growth on glycerol is achieved by triethyllead acetate at a concentration $(50 \mu \mathrm{M})$ that inhibits respiration in similar cell suspensions by about $45 \%$. The same concentration applied to cells growing on glucose reduces the growth rate by about $90 \%$ whilst inhibiting $\mathrm{O}_{2}$ uptake by only $15 \%$. Tripropyllead acetate exhibited an $\mathrm{I}_{50}$ for respiration rates of $10 \mu \mathrm{M}$ while the growth rate of cultures of similar turbidity was substantially reduced at $1 \mu \mathrm{M}$. These data make it unlikely that the inhibition of respiration rates alone accounts for the growth-inhibitory properties of the trialkyllead compounds. Leow \& Leaver (1977) demonstrated that growth of $E$. coli was inhibited by triethyltin compounds to a greater extent in succinate- than glucosecontaining medium.

The greater efficacy of the tripropyl rather than triethyl derivatives in inhibiting growth and respiration is probably a direct consequence of the greater liposolubility of compounds bearing the longer alkyl chains. Similar structure-activity relationships have previously been observed for the action of trialkyllead and trialkyltin compounds on mitochondrial functions (Aldridge, 1976; Aldridge et al., 1977) and the inhibition by a series of trialkyltin chlorides of the growth of diverse micro-organisms (Yamada et al., 1978). We have not investigated derivatives with alkyl groups longer than three carbon atoms; however, growth-inhibitory activity declines when the alkyl chain of organotins is longer than $\mathrm{C}_{4}$ (Yamada et al., 1978) and biochemical activity of the highly hydrophobic organotins (triphenyltin and tricyclohexyltin) is reduced (Selwyn, 1976).

The inhibition of respiratory electron transfer by triorganotins and triorganoleads is one of several perturbations that these compounds exert on energy-linked functions. At high concentrations of trialkyltin compounds, direct inhibition of electron transfer in chloroplasts has been observed (Kahn, 1968; Watling-Payne \& Selwyn, 1974) and is probably a result of the detergent-like disorganization of the respiratory chain. In halide-containing media, various triorganoleads and triorganotins stimulate $\mathrm{O}_{2}$ uptake and ATP hydrolysis in mitochondria (Aldridge et al., 1977), as a result of the restricted uncoupling that occurs when these agents mediate a $\mathrm{OH}^{-} /$halide antiport (see below). At low $\mathrm{pH}$ (Coleman \& Palmer, 1971) and in the presence of appreciable concentrations of $\mathrm{Cl}^{-}$, this antiport tends to clamp the transmembrane $\mathrm{pH}$ difference, acid inside (Selwyn, 1976), and inhibits uncoupler-stimulated respiration (Dawson \& Selwyn, 1974). In the present study, the $\mathrm{Cl}^{-}$ content of the assay medium (44 mM) was similar to that required (40 to $80 \mathrm{~mm}$; Aldridge et al., 1977) to produce half-maximal uncoupling in mitochondria by trialkyllead compounds. However, the observation that the concentrations of trialkyllead compounds required for $50 \%$ inhibition of particle respiration exceed by three orders of magnitude the concentrations required to mediate $\mathrm{OH}^{-} / \mathrm{Cl}^{-}$exchange suggests that the inhibitions of substrate oxidation and respiratory chain reduction are direct effects on electron transfer. All cytochromes, except $a_{1}$, were substantially less reduced by NADH in the presence of triethyllead acetate suggesting a site of inhibition on the substrate side of the cytochromes. A similar site of action has been proposed for triethyltin in mitochondria (Coleman \& Palmer, 1971). At least two explanations may be offered for the changed ratio of reduced cytochromes $b$ and $d$ in the steady state in the presence of trialkyllead acetate (Fig. $4 a, b$ ). Both invoke cytochrome $o$ as a $b$-type cytochrome that makes a major contribution to the Soret region of the spectrum and acts as an alternative oxidase to cytochrome $d$ in a branched electron transport chain (Downie \& Cox, 1978). The ratio of Soret absorbance $(417-432 \mathrm{~nm}$ ) to that in the $\alpha$-region $(551-568 \mathrm{~nm})$ in CO difference spectra is $26: 1$ for cytochrome $o$ (Daniel, 1970). Firstly, triethyllead acetate may act at a second site located between other cytochromes $b$ (perhaps $b_{556}$ ) and $o$, such that the diminished electron flux from low potential carriers is carried solely or largely through the limb terminated by cytochrome $d$ instead of through both oxidases. Alternatively, the changed ratio of reduction of $o$ and $d$ in the 
presence of organolead could result from the different $\mathrm{O}_{2}$ affinities of these oxidases (Rice \& Hempfling, 1978). The $\mathrm{O}_{2}$ concentrations at the times of freezing the uninhibited and lead-inhibited samples were similar but not identical, being 6.8 and $9.0 \mu \mathrm{M}$, respectively. Since cytochrome $d$ has a higher affinity for $\mathrm{O}_{2}$ than does $o$, poising of the respiratory chain at lower $\mathrm{O}_{2}$ concentrations (in the uninhibited particles) could result in a higher ratio of oxidation of cytochrome $d$ to $o$ than is observed at higher $\mathrm{O}_{2}$ tensions. No detailed profiles of the extent of oxidation of cytochromes $o$ and $d$ poised at different $\mathrm{O}_{2}$ tensions have been published but the reported $K_{\mathrm{m}}$ values for the oxidases are quite different, being 0.2 and $0.024 \mu \mathrm{M}$, respectively (Rice \& Hempfling, 1978), making this second explanation unlikely.

Mitchell (1963) first suggested that trialkyltin salts acted as uncouplers by carrying $\mathrm{OH}^{-}$ rather than $\mathrm{H}^{+}$. Subsequently, it has been shown that triorganotins mediate the exchange" of $\mathrm{Cl}^{-}$and $\mathrm{OH}^{-}$across many natural membranes (Selwyn et al., 1970; Watling-Payne \& Selwyn, 1970), including the cytoplasmic membranes of E. coli (Fulton \& Selwyn, unpublished; cited in Selwyn, 1976). We have extended previous observations on the $\mathrm{Cl}^{-}-$ dependent effects of triorganolead compounds (for references, see Aldridge et al., 1977) and demonstrated that in E. coli $1 \mu \mathrm{M}$-triethyllead mediates a $\mathrm{Cl}^{-} / \mathrm{OH}^{-}$or $\mathrm{Br}^{-} / \mathrm{OH}^{-}$ antiport but not antiports for the $\mathrm{F}^{-} / \mathrm{OH}^{-}, \mathrm{SO}_{4}{ }^{2-} / \mathrm{OH}^{-}$or $\mathrm{NO}_{3}{ }^{-} / \mathrm{OH}^{-}$couples. The requirement for CCCP before swelling occurred in iso-osmotic $\mathrm{NH}_{4} \mathrm{NO}_{3}$ demonstrates that triethyllead cannot act as a proton uniport. Triorganotins do not function as either $\mathrm{Cl}^{-}$or $\mathrm{OH}^{-}$uniporters (Selwyn et al., 1970). The finding that triethyllead did not induce swelling in iso-osmotic $\mathrm{NaBr}$ was surprising in view of the observed $\mathrm{Br}^{-} / \mathrm{OH}^{-}$antiport system and the presence of a Na$~ N^{+} / \mathrm{H}^{+}$antiport in $E$. coli (West \& Mitchell, 1974). Together, these should allow the non-electrogenic uptake of $\mathrm{NaBr}$ (Fig. $6 c$ ). However, at $\mathrm{Na}^{+}$concentrations greater than $75 \mathrm{~mm}$, the latter antiport appears to be saturated with $\mathrm{Na}^{+}$and functions as a $\mathrm{Na}^{+} / \mathrm{Na}^{+}$antiport (West \& Mitchell, 1974). Furthermore, the attempts of West \& Mitchell (1974) to demonstrate a $\mathrm{Na}^{+} / \mathrm{H}^{+}$antiport analogous to that observed in mitochondria (Mitchell \& Moyle, 1969) using the osmotic swelling technique were also ambiguous.

The potency of triethyllead as an inhibitor of the membrane-bound ATPase activity was independent of the presence of $\mathrm{Cl}^{-}$. Similar experiments on the effect of triorganotins on the ATPases of E. coli (Selwyn, 1976) and chloroplasts (Gould, 1976) show that the solubilized enzyme is insensitive; the site of action of these triorganometallic compounds is, therefore, probably on the $F_{o}$ component of the enzyme as is the site of action of oligomycin, DCCD and other inhibitors. Further studies on the action of triorganoleads on the ATPase are being pursued in these laboratories.

We acknowledge the efforts of J. Weschler in the early stages of this work.

\section{REFERENCES}

AldRIDGE, W. N. (1976). The influence of organotin compounds on mitochondrial functions. In Organotin Compounds: New Chemistry and Applications (Advances in Chemistry Series 157), pp. 186-196. Edited by J. J. Zuckerman. Washington: American Chemical Society.

Aldridge, W. N. \& Street, B. W. (1964). Oxidative phosphorylation. Biochemical effects and properties of trialkyltins. Biochemical Journal 91, 287-296.

Aldridge, W. N. \& STreet, B. W. (1971). Oxidative phosphorylation: relation between specific binding of trimethyltin and triethyltin to mitochondria and their effects on various mitochondrial functions. Biochemical Journal 124, 221-234.

Aldridge, W. N., Street, B. W.\& Skilleter, D. N. (1977). Oxidative phosphorylation. Halide-dependent and halide-independent effects of triorganotin and triorganolead compounds on mitochondrial functions. Biochemical Journal 168, 353-364.

BolanowsKa, W. (1968). Distribution and excretion of triethyllead in rats. British Journal of Industrial Medicine 25, 203-208.

Cain, K., Partis, M. D. \& Griffiths, D. E. (1977a). Dibutylchloromethyltin chloride, a covalent 
inhibitor of the adenosine triphosphate synthase complex. Biochemical Journal 166, 593-602.

Cain, K., Hyams, R. L. \& Griffiths, D. E. (1977b). Studies on energy-linked reactions: inhibition of oxidative phosphorylation and energy-linked reactions by dibutyltin dichloride. FEBS Letters 82, 23-28.

Chance, B. \& Schoener, B. (1966). High and low energy states of cytochromes. I. In mitochondria. Journal of Biological Chemistry 241, 4567-4573.

Coleman, J. O. D. \& Palmer, J. M. (1971). The influence of $\mathrm{pH}$ on the inhibition of oxidative phosphorylation and electron transport by triethyltin. Biochimica et biophysica acta 245, 313-320.

Cremer, J. E. (1962). Tetraethyllead toxicity in rats. Nature, London 195, 607-608.

DANIEL, R. M. (1970). The electron transport system of Acetobacter suboxydans with particular reference to cytochrome $o$. Biochimica et biophysica acta 216, 328-341.

Dawson, A. P. \& Selwyn, M. J. (1974). The action of trialkyltin compounds on mitochondrial respiration. The effect of pH. Biochemical Journal 138, 349-357.

DegN, H., Lilleør, M. \& Iversen, J. J. L. (1973). The occurrence of a stepwise-decreasing respiration rate during oxidative assimilation of different substrates by resting Klebsiella aerogenes in a system open to oxygen. Biochemical Journal 136, 1097-1104.

Downie, J. A. \& Cox, G. B. (1978). Sequence of $b$ cytochromes relative to ubiquinone in the electron transport chain of Escherichia coli. Journal of Bacteriology 133, 477-484.

Garland, P. B., Downie, J. A. \& Haddock, B. A. (1975). Proton translocation and the respiratory nitrate reductase of Escherichia coli. Biochemical Journal 152, 547-559.

Gibson, J. F., Hughes, M. N. \& Poole, R. K. (1979). Inhibition of growth and energy metabolism of Escherichia coli by triorganolead compounds. Society for General Microbiology Quarterly 6, 74.

GouLD, J. M. (1976). Inhibition by triphenyltin chloride of a tightly-bound membrane component involved in phosphorylation. European Journal of Biochemistry 62, 567-575.

HadDock, B. A., Downie, J. A. \& Garland, P. B. (1976). Kinetic characterization of the membranebound cytochromes of Escherichia coli grown under a variety of conditions by using a stoppedflow dual wavelength spectrophotometer. Biochemical Journal 154, 285-294.

KAHN, J. S. (1968). Chlorotri-n-butyltin. An inhibitor of phosphorylation in isolated chloroplasts. Biochimica et biophysica acta 153, 203-210.

LeOW, A. C. T. \& Leaver, D. D. (1977). Effect of triethyltin on Escherichia coli K12. ChemicoBiological Interactions 19, 339-351.

Mrtchell, P. (1963). Molecule, group and electron translocation through natural membranes. Biochemical Society Symposia 22, 142-168.

Mitchell, P. \& MoYle, J. (1969). Translocation of some anions, cations and acids in rat liver mitochondria. European Journal of Biochemistry 9, 149-155.
PIRT, S. J. (1967). A kinetic study of the mode of growth of surface colonies of bacteria and fungi. Journal of General Microbiology 47, 181-197.

Poole, R. K. (1977). The influence of growth substrate and capacity for oxidative phosphorylation on respiratory oscillations in synchronous cultures of Escherichia coli K12. Journal of General Microbiology 99, 369-377.

Poole, R. K. \& Haddock, B. A. (1974). Energylinked reduction of nicotinamide-adenine dinucleotide in membranes derived from normal and various respiratory-deficient strains of Escherichia coli. Biochemical Journal 144, 77-85.

Rice, C. W. \& Hempfling, W. P. (1978). Oxygenlimited continuous culture and respiratory energy conservation in Escherichia coli. Journal of Bacteriology 134, 115-124.

Rose, M. S. \& Aldridge, W. N. (1972). Oxidative phosphorylation: the effect of anions on the inhibition by triethyltin of various mitochondrial functions, and the relationship between this inhibition and binding of triethyltin. Biochemical Journal 127, 51-59.

SELWYN, M. J. (1976). Triorganotin compounds as ionophores and inhibitors of ion translocating ATPases. In Organotin Compounds: New Chemistry and Applications (Advances in Chemistry Series 157), pp. 204-226. Edited by J. J. Zuckerman. Washington: American Chemical Society.

Selwyn, M. J., Dawson, A. P., Stockdale, M. \& GaINES, N. (1970). Chloride-hydroxide exchange across mitochondrial, erythrocyte and artificial lipid membranes mediated by trialkyl- and triphenyltin compounds. European Journal of Biochemistry 14, 120-126.

SHIPP, W. S. (1972). Cytochromes of Escherichia coli. Archives of Biochemistry and Biophysics 150, 459-472.

Stevens, C. D., Feldhake, C. J. \& Kehoe, R. A. (1960). Isolation of triethyllead ion from liver after inhalation of tetraethyllead. Journal of Pharmacology and Experimental Therapeutics 128, 90-94.

Stockdale, M., Dawson, A. P. \& Selwyn, M. J. (1970). Effects of trialkyltin and triphenyltin compounds on mitochondrial respiration. European Journal of Biochemistry 15, 342-351.

TsuchIYA, T. \& Rosen, B. P. (1975). Energy transduction in Escherichia coli. The role of the $\mathrm{Mg}^{2+}$ ATPase. Journal of Biological Chemistry 250, 8409-8415.

Watling-Payne, A. S. \& Selwyn, M. J. (1970). Effect of some organometallic compounds on the permeability of chloroplast membranes. FEBS Letters 10, 139-142.

Watling-Payne, A. S. \& Selwyn, M. J. (1974). Inhibition and uncoupling of photophosphorylation in isolated chloroplasts by organotin, organomercury and diphenyleneiodonium compounds. Biochemical Journal 142, 65-74.

West, I. C. \& Mitchell, P. (1974). Proton/sodium ion antiport in Escherichia coli. Biochemical Journal 144, 87-90.

Yamada, J., Tatsuguchi, K. \& Watanabe, T. (1978). Effects of trialkyltin chlorides on microbial growth. Agricultural and Biological Chemistry 42, 1167-1172. 